VIEWING THE PROPOSED SOUTH AFRICAN BUSINESS

RESCUE PROVISIONS FROM AN AUSTRALIAN PERSPECTIVE

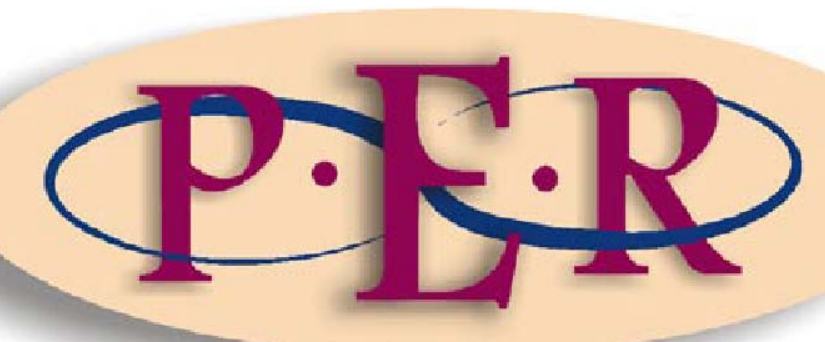

2008 VOLUME 11 NO 1 


\section{VIEWING THE PROPOSED SOUTH AFRICAN BUSINESS RESCUE PROVISIONS FROM AN AUSTRALIAN PERSPECTIVE}

\section{Anderson*}

\section{$1 \quad$ Introduction}

Australia and South Africa share more than sporting rivalry. In legal terms there is much that has come from the common Anglo heritage. The company law regime in both countries has much in common. However, it is one matter to have common legislation it is another to have that legislation operate in the same manner given different social conditions and a different commercial environment. Further in more recent times it is likely to be the influences of a number of factors that will play a part in law reform in each country not just what happens in the United Kingdom. Nevertheless there is value in making comparisons of the legislative regime in each jurisdiction where the stated aims are the same and where one jurisdiction may have a history that may show how proposed legislation in another may operate. Such similarity may be found in the legislation proposed in the South African Companies Bill 2007 to enable business rescue. ${ }^{1}$ The Australian equivalent can be broadly found in Part 5.3A of the Corporations Act 2001 (Cth). Like South Africa, Australia includes its corporate insolvency provisions in its general company law statute. ${ }^{2}$ This article seeks to make comparisons between the existing Australian regime and the proposed South African legislation. This article does not however engage in the

* Dr Colin Anderson, Griffith Business School, Griffith University Australia.

1 Companies Bill 2007 ch 6.

2 Although there appears that there is a proposal in South Africa to bring all insolvency law within the one piece of legislation, this does not appear to be in accordance with the approach adopted in the Companies Bill 2007: see Burdette Comments on the Companies Bill appendix 7 to submission by TMA-SA on Draft Companies Bill 2007 at 4. 
convergence debate. ${ }^{3}$ It is not suggested here that legislation is nor indeed should, be converging towards some ideal that will be a preferable model in all jurisdictions. What it does is to examine some aspects of the proposed legislation in South Africa and compare that to the equivalent Australian regime from an Australian perspective. By so doing it may assist in the debate in South Africa over how the legislation is framed as the experience in Australia may be useful as an indicator of issues to be considered.

\section{The background to 'business rescue' in Australia}

Prior to making any comment on the South African proposals from an Australian view, the background to the Australian legislation is discussed briefly below. This provides some context to the Australian provisions which assists in evaluating the themes in the legislation. The first point of note is that Australia does not have a separate insolvency statute but maintains its corporate insolvency provisions within its general Corporations Act. ${ }^{4}$ The legislation governing companies always had as a fundamental procedure liquidation provisions. The development of insolvency law in Australia did not necessarily occur in a coherent display of principle applicable to both individuals and corporations but more often as a series of specific issues dealt with when some form of crisis developed that needed to be managed. The notable exception to this occurred when the Australian Law Reform Commission examined insolvency law generally in its 1988 report. ${ }^{5}$ The separation of corporate and personal insolvency reflects the English heritage of Australian law in this area.

3 This argument being that legislation in various jurisdictions should converge towards standard provisions - generally those adopted in the United States or the United Kingdom.

4 See generally ch 5 Corporations Act 2001 (Cth).

5 ALRC Harmer Report http://www.alrc.gov.aul 11 Feb. The current business rescue provisions are as a direct result of recommendations of that inquiry so it is no coincidence that they represent a more coherent and encapsulated procedure. 


\subsection{Early developments - scheme of arrangement}

Australian company law generally (and its corporate insolvency laws in particular) has developed from statutes in individual states. For reasons to do with the interpretation of the Corporations power in the Australian Constitution, company law was until the 1980's left essentially as a state matter. Despite the integration of commercial activity throughout Australia, company legislation did not always provide for consistent treatment even in matters of corporate insolvency.

Specifically in relation to provisions aimed at 'rescuing' companies in financial difficulties, the earliest adopted procedure was the scheme of arrangement. ${ }^{6}$ This was initially developed in the UK legislation through a series of pieces of legislation starting with the Joint Stock Companies Arrangement Act in 1870. By 1928 in the English legislation, the philosophical basis of the scheme of arrangement sections (as they currently exist in Australian legislation) had been established. The development of the sections in Australia followed almost directly from the English provisions. ${ }^{7}$ These types of provisions were adopted in many jurisdictions with an Anglo legal heritage and will be familiar as they are found in the current South African Companies Act 61 of $1973 .^{8}$ When the Harmer Report recommended the adoption of a new form of corporate rescue it did not suggest that it replace the scheme of arrangement provisions rather that they needed to be kept to deal with reconstructions and for larger arrangements in insolvency. ${ }^{9}$

6 For a more detailed examination of the background of Schemes of Arrangement and their relationship to the business rescue provisions in Australia see Anderson 1999 Australian Journal of Corporate Law 107.

7 Queensland inserted provisions equivalent to s 2 of the UK Act of 1870 in 1889 and New South Wales and Victoria followed in 1892. By 1937, all Australian states except Western Australia had adopted almost identical provisions to those of $S 120$ of the 1908 United Kingdom Act: see Pilcher, Uther and Baldock Australian Companies Act at 269.

8 See ch XII and specifically s 311.

9 ALRC Harmer Report http://www.alrc.gov.au/ 11 Feb at par 57. 


\subsection{Official management}

This form of insolvency administration was inserted in the State based Companies Acts and subsequently adopted in national scheme legislation. It was based upon the South African Judicial Management procedure. Unlike the South African provisions however the appointment of the official manager in Australia was done by a meeting of creditors $^{10}$ rather than by the Court. ${ }^{11}$ In many other respects the procedure was similar in both jurisdictions. The procedure has some common goals with the current business rescue procedure in Australia (referred to here as Part $5.3 \mathrm{~A})^{12}$ in that it is also designed to allow companies that are in financial difficulties to be saved but if this is not possible that they be wound up. However, at least in the Australian context, there was a major difficulty of the procedure which is not evident in its replacement in Part 5.3A in that official management required that the debts be paid in full within a set time. This was a major hurdle for insolvent companies. As a result of this requirement, it was noted by the Harmer Report ${ }^{13}$ that "official management is rarely attempted". The lack of usage of the procedure meant that there was little concern when these provisions were removed from the legislation on the commencement of Part 5.3A in $1993 .{ }^{14}$ It is notable that the South African proposal will also remove judicial management from the legislation. ${ }^{15}$

10 See the former s 335 Companies Act 1981 (Cth).

11 See in the South African Companies Act 61 of 1973 s 427, 428 and 432.

12 The Australian rescue procedure is encapsulated in Part 5.3A of the Corporations Act 2001 (Cth). This part is often referred to as 'voluntary administration' but it should be noted that the part also contains provisions dealing with a 'deed of company arrangement' which is a rescue plan that may be adopted only as a result of the voluntary administration although creditors may instead vote in favour of a winding up of the company instead.

13 ALRC Harmer Report http://www.alrc.gov.au/ 11 Feb at par 47.

14 See Corporate Law Reform Act 1992 (Cth).

15 DTI Explanatory Memorandum Companies Bill 200714. 


\subsection{Development of voluntary administration}

Apart for the insertion of official management provisions in the Companies Acts no further legislative development took place in the area of arrangement or compromise until the 1980s in Australia. This interest in insolvency legislation in Australia was probably sparked again from developments in the United Kingdom where the process of review of insolvency law could be traced back to the mid seventies. As Fletcher and Crabb suggest: ${ }^{16}$

It is also worthwhile to recall that the reforms ... were the product of an extended process of re-examination of the entire working of the insolvency law which began to gain in urgency in the period from 1975 onwards, as successive phases of economic recession brought about abnormally high levels of corporate and individual financial failures.

No doubt the economic conditions in Australia were similarly the catalyst for the instigation of the Harmer Report. It is interesting to note in this regard that despite the delivery of the Harmer Report in 1988, it was not until the severe economic downturn of 1990 that legislation implementing the corporate reforms was introduced. In this sense the reform of the provisions relating to arrangements with creditors, with its emphasis on the continuity of the business and subsequent employment, was seen as a key feature of the response to corporate insolvency. ${ }^{17}$ It is not clear to this author if such economic conditions may be the driver for the interest in such procedures in South Africa.

\subsection{Developments since the implementation of Part 5.3A}

Since its implementation in 1993, the provisions in Part 5.3A remained relatively untouched until some recent amendments passed in August 2007.

16 Fletcher and Crabb Insolvency Act at 45-15.

17 The Harmer Report, supra n 5, did not recommend that voluntary administration replace the scheme of arrangement provisions. In par 57 the recommendation was that: "schemes of arrangement should be preserved for, in particular, larger private or public companies (although it is not suggested that this procedure should be limited to such companies)". 
The government did receive a comprehensive review of the legislation in 1998 when the legal committee of the Companies and Securities Advisory Committee (CASAC) presented a report on the operation of Corporate Voluntary Administration. ${ }^{18}$ Subsequently the Joint Parliamentary Committee on Corporations and Financial Services undertook a general enquiry into Australia's insolvency law. ${ }^{19}$ The collapse of the Ansett group ${ }^{20}$ of companies in 2001 in particular, was the impetus for the consideration by the Corporations and Markets Advisory Committee (CAMAC) on rehabilitating large enterprises. ${ }^{21}$ The Ansett case showed the difficulty of using Part 5.3A in relation to a larger company. One of the matters considered by CAMAC was whether the adoption of a corporate rescue model that provided for debtor in possession during the period of rescue and for entering into the procedure before a company is insolvent was required. Ultimately none of the reviews recommended that these matters be incorporated and accepted that the current provisions worked satisfactorily. It was believed that with relatively minor amendments the legislation could become flexible enough to cover larger insolvencies. This resulted in the Corporations Amendment (Insolvency) Act 2007 being passed in August 2007. At the time of writing these changes which are not fundamental - have yet to be proclaimed and hence are not in operation. As these amendments have just passed through the Parliament and are not yet in operation it may be some time before the predictions will be put to

18 Legal Committee of the CASAC Corporate Voluntary Administration Final Report June 1998. This review made sixty recommendations but only some were subsequently adopted in the 2007 amendments.

19 Some insight into where this very broad ranging enquiry may head can be found in the Parliamentary Joint Committee Issue Paper http://www.aph.gov.au/ 14 Feb.

20 Details of the Ansett administration may be found at http://www.ansett.com.au. The airline went into administration on 12 September 2001. Although not a large company by world standards (debts were estimated at around \$A2b) it was a significant company by Australian standards. It was also the country's second largest airline and was considered an icon in the aviation industry in a country that relies heavily on air transport. There were some 15,000 employees and perhaps most significantly there was a looming Federal election.

21 CAMAC Discussion paper http://www.camac.gov.au 14 Feb.

$$
109 / 211
$$


the test. This article deals with the Australian law as it currently exists and does not attempt to analyse the amendments not yet in force.

\section{The aims of the procedures}

The provisions dealing with corporate rehabilitation in Australia are contained in Part 5.3A of the Corporations Act. In section 435A there are objects stated which apply to the whole of the Part. These state that the business property and affairs of the company are administered in such a way that maximises the chances of the company or as much of it as possible surviving. However if that is not possible the secondary object is that the return to creditors and members is better than would have resulted from an immediate winding up. These objects have been utilised by the courts on occasion to assist in interpretation of sections in Part 5.3A. ${ }^{22}$ It has been accepted that it is possible to use the procedure despite there being no intention to have the company or its business survive. ${ }^{23}$ Thus the second object is considered a worthwhile goal in itself so as to justify the adoption of the procedure in preference to moving directly into a winding up. The courts in Australia have been careful not to allow the Part 5.3A procedure to be used where there appears to be an ulterior purpose behind the appointment of an administrator by directors. ${ }^{24}$

Set out in a proposed new South African Companies Act is a chapter 6 headed 'Business Rescue'. The term 'business rescue' is proposed to be defined in section 130 as "proceedings to facilitate the rehabilitation by its management of a company that is insolvent or may become insolvent". The definition then

22 See eg Australasian Memory v Brien (2000) 200 CLR 270 and Kalon v Sydney Land Corp [No 2] (1998) 26 ACSR 593.

23 In Dallinger $v$ Halcha Holdings (1996) 14 ACLC 263 where Sundberg j held (at 268) that the machinery in Part 5.3A should be available "where, although it is not possible for the company to continue in existence, an administration is likely to result in a better return for creditors".

24 Aloridge v Christianos (1994) 12 ACLC 237; Kazar v Duus (1998) 29 ACSR 321. 
identifies the proceedings as temporary supervision of management with a temporary moratorium on the rights of claimants against the company or its property and the development and implementation of a plan to rescue the company (if approved). As with the Australian provisions these activities are to have objects which are stated as maximising the likelihood of the company continuing on a solvent basis or if not possible results in a better return for the company's creditors or shareholders.

Therefore there are almost identical aims with both procedures. Each jurisdiction recognises the desirability of the company continuing in existence so that the legislation assumes that this is a desirable goal. Both jurisdictions appear to reject therefore the argument that corporate rescue legislation has the effect of adding to costs for creditors and is likely to be used strategically by management to delay or defeat creditors. ${ }^{25}$ It reflects the wide acceptance that the retention of the corporate entity or at least a significant portion of its business even though it may be insolvent adds value to society more generally and is a desirable form of insolvency legislation over straight liquidation. ${ }^{26}$ Further there is recognition that even though the company may not continue in existence it is suggested that better returns may be gained by adopting the rescue procedure. ${ }^{27}$

25 Most influentially, see Jackson Logic and Limits of Bankruptcy Law, and also Baird 1986 Journal of Legal Studies 127. More recently there has been Baird and Rasmussen 55 Stanford Law Review 751. None of this criticism has been effective though in persuading jurisdictions not to provide for corporate rescue in legislation. However it must be recognised that the form of the legislation does vary from that used in the US which is the source of most of this critical analysis.

26 It is possible to speculate on why the use of rescue type provisions has become popular at least in terms of them appearing in insolvency statutes around the world. It may be that economic development has resulted in less business activity in manufacturing as well as the growth in human capital. Each of these suggests that the value in an enterprise rests less on the physical assets and more in the personal expertise and knowledge that the staff and managers bring to the firm. It is more likely that this can be retained if the corporate structure is retained.

27 It is more difficult to postulate a reason why this may be correct and a most likely explanation may be that it is not possible to predict prior to the attempt to rescue the firm whether it will be successful. Hence it may simply be a case of allowing for the rescue on the chance that it will succeed but if it does not, there are relatively few additional costs $111 / 211$ 


\section{Commencement}

One area of relevance when comparing the proposed South African and the Australian systems is in relation to how the procedures are commenced. All corporate rescue systems have three distinct steps - commencement, investigation and development of plans, and decision making. It is possible to identify the commencement phase of the Australian provisions as being one that does not seek to evaluate the desirability of the company entering into the process. In common with other jurisdictions, the procedure is designed so that it is relatively simple to enter the procedure. Procedurally, the Australian voluntary administration process commences by the appointment of an administrator. ${ }^{28}$ The appointment of an administrator can be made by three distinct parties. Firstly the board of directors may appoint an administrator by way of a resolution provided that the board is of the opinion that the company is insolvent or about to become insolvent. ${ }^{29}$ Although no statistics are kept on the manner of appointment, the widely accepted view is that this is by far the most common manner in which an administrator is appointed in Australia. Secondly, the appointment may be made by a liquidator or provisional liquidator if he or she thinks that the company is insolvent or about to become so. ${ }^{30}$ The only limitation here is that if the liquidator wishes to appoint himself or herself, leave of the court must be obtained. Finally, an appointment may be made by a secured creditor who has a charge over the whole or substantially the whole of the company's property if the secured creditor is entitled to enforce the charge. ${ }^{31}$ Where the company is already being wound up the appointment may

compared to an immediate liquidation. On the other hand the benefits from a successful rehabilitation are considerable and may outweigh these costs.

28 See s 435C(1) Corporations Act 2001 (Cth).

29 See s 436A(1) Corporations Act 2001 (Cth).

30 See s 436B(1) Corporations Act 2001 (Cth).

31 See s 436C(1) Corporations Act 2001 (Cth). 
not be made by either the board or the secured creditor. Somewhat unusually, in Australia there is no provision for a court to make an order that an administrator be appointed. The above three persons are the only ones who can make such an appointment. Neither shareholders nor ordinary creditors can effect an appointment of an administrator. This results in a practical sense of the board having the control of this type of appointment.

The reasoning behind the Australian approach was the recognition of two separate features of corporate insolvency. One was the recognition that court based systems as adopted in jurisdictions such as the United States often led to delays and costly litigation that resulted in even smaller dividends for creditors. $^{32}$ The aim was to avoid the dissipation of the company's remaining funds in such activities. At that time little consideration was given to the fact that the United States system did provide some relief in relation to those costs by allowing the debtor to remain in possession in many instances hence the day to day running of the company was not in the hands of a professional accountant as in Australia. ${ }^{33}$ The second reason for allowing the procedure to commence in this way was to ensure that the directors were able to deal with the company's insolvency in a swift and effective manner. The moral hazard associated with management of an insolvent company is well documented ${ }^{34}$ and the Harmer Report recognised the fact that board will often hold out once a company approaches insolvency in the belief that there is an improvement just

32 ALRC Harmer Report http://www.alrc.gov.au/ 11 Feb at par 54.

33 The administration of the company is undertaken by a professional accountant who will charge not only for her or his services but also for employees, etc. the costs here will always include the time taken to learn about the firm and its operations. Thus there is no doubt that additional expense is the likely result. However it is generally seen as fundamental to the Australian regime that an independent qualified person be appointed to both run the company and report to creditors. As such there has been little support for a suggestion that Australia adopt a debtor in possession approach: see CAMAC Report http://www.camac.gov.au 14 Feb, which concluded (at 17) that "[m]ost submissions agreed that there was no compelling case for fundamental changes to Part 5.3A along the lines of the debtor in possession model".

34 See eg the discussion in Barondes 1998 George Mason Law Review 45 particularly at 4851. It may be noted that Barondes argues that such behaviour is not necessarily evident in empirical studies. 
around the corner or that there is nothing to lose in continuing ${ }^{35}$ The Harmer Report had sought to remove the incentive to continue the company by introducing a more effective regime to punish directors who allow the company to trade whilst it was insolvent whilst providing them with a means of dealing with the insolvency. Thus it was something of a carrot and stick approach in that the directors are open to liability where the company is allowed to trade on when insolvent but there is a simple cheap means of dealing with the insolvency.

The proposed South African legislation provides for a 'business rescue' ${ }^{136}$ that may be commenced in one of three ways, by ordinary resolution of the shareholders, ordinary resolution of the board ${ }^{37}$ or by a court order ${ }^{38}$ In relation to the appointment by the board of directors this has similarity to the Australian procedure. However it does not appear that the strict prohibition on insolvent trading that was introduced in Australia at the same time as the voluntary administration regime has been pursued in the South African provisions. Although there is a reformulation of the directors' duties in the proposed new legislation it does not directly prohibit directors allowing company trading whilst the company is insolvent as is done in Australia. Thus there may not be quite the same incentive to pursue the rescue option by directors.

In relation to the appointment by the shareholders' resolution, this has echoes of the voluntary winding up procedure. This option was not adopted in Australia even though it was specifically considered by the Harmer Committee. ${ }^{39}$ The route to the procedure via a resolution of the board of directors seems a much more direct one and it is unclear under what circumstances the shareholders would adopt this approach without some support from the board. That is not to

35 ALRC Harmer Report http://www.alrc.gov.au/ 11 Feb at par 53.

36 See proposed ch $6 \mathrm{~s} 130$, definition.

37 Proposed s 132.

38 Proposed s 134.

39 ALRC Harmer Report http://www.alrc.gov.au/ 11 Feb at par 64. 
suggest such a provision is not suitable as members may be more involved in South African companies than in Australia. There is in fact something of a gap in the Australian procedure in terms of how it deals with the shareholder interests in the company. The fundamental theme in the Australian provisions is that the shareholders have no proprietary interest left in the insolvent company. However it can be argued that this reflects more of a liquidation perspective of the insolvency procedure. That is, the shareholders may have no interest in an entity that is being wound up with no funds available for any stakeholders but the outside creditors, but a corporate rescue is more likely - if it is successful to mean a continuing interest in the corporate entity from the shareholders. The approach in Australia also shows the emphasis placed upon director responsibility for the actions of the corporations. The legislation adopts a model that makes the board almost entirely responsible for the corporation with the other stakeholders ${ }^{40}$ reduced to outsiders. ${ }^{41}$ The Harmer Report rejected such a provision on the basis that -

company law has reposed responsibility for the management of companies with the directors rather than the members. ${ }^{42}$

The commencement of the procedure by the court under proposed section 134 is also a point of departure from the Australian procedure. Under the proposed section 134 an application requires that an 'insolvency event' must have occurred in relation to the company and the company must not have already entered the procedure. An insolvency event will have occurred if the company fails to satisfy a statutory demand, execution on a judgement against the company is returned unsatisfied or the court is satisfied the company is unable to pay its debts. ${ }^{43}$ If such an event has occurred then any affected person may apply to the court. An affected person is proposed to be a shareholder, creditor,

40 Including members.

41 In some respects this reflects a director primacy model of the company: see Bainbridge 2003 Northwestern University Law Review 547.

42 ALRC Harmer Report http://www.alrc.gov.au/ 11 Feb at par 64.

43 Proposed s 131. 
registered trade union or employee who is not a trade union member. ${ }^{44}$ This will open up a wide range of stakeholders who may apply to the court. By allowing individual shareholders to apply it potentially opens up a large number of applicants as there appears to be no restriction on that right. ${ }^{45}$ In the case of the right of creditors, in Australia the Harmer Report specifically rejected an argument to allow them to apply to the court for an appointment of an administrator. ${ }^{46}$ This was based on the voluntary nature of the procedure and the potential delay and costs that may result because of the court procedure. In a subsequent review of the Part 5.3A procedure it was however recommended ${ }^{47}$ that the court be given power to appoint an administrator on an application by a creditor as an alternative to asking for the winding up. ${ }^{48}$ This has not been taken up in the 2007 amendments. ${ }^{49}$ The South African approach of allowing creditors to apply does provide some opportunity for creditors to initiate action to deal with the insolvency of the company whilst at the same time providing for a potential rescue. It may be that in most situations the creditor will prefer a liquidation but the opportunity should not be denied as in Australia. $^{50}$

In the Australian system of voluntary administration, the procedure commences upon the appointment of the administrator. ${ }^{51}$ The proposed South African provisions provide that the business rescue proceedings begin when the

44 As to be defined in proposed $\mathrm{s} 130$.

45 In Australia there is no right to apply for the appointment of an administrator by the court. However in relation to liquidation the right to apply by individual shareholders is restricted by the need to obtain leave of the court for a winding up in insolvency: see s 459P.

46 ALRC Harmer Report http://www.alrc.gov.au/ 11 Feb at par 65.

47 By the Companies and Securities Advisory Committee (CASAC). This is a government funded advisory group which advises on corporate and related law issues. It has now been re-named as the Corporations and Markets Advisory Committee (CAMAC).

48 Legal Committee, supra n 18 at par 7.8-7.9.

49 Corporations Amendment (Insolvency) Act 2007 (Cth).

50 A further inequity in the Australian provisions is the fact that a chargeholder whose charge is over the whole or substantially the whole of the assets may appoint an administrator but no other creditor may do so. For a discussion of the problems with this see Anderson 2001 Insolvency Law Journal 4.

51 See s 435C. 
company files with the Commission a resolution to place itself under supervision or when a person files an application to the court for an order. ${ }^{52}$ What is of interest is that under the proposed section 132(3) in the South African regime is the fact that the company must appoint a supervisor within five business days after filing the resolution that the company begin the business rescue procedure. This suggests that the company may be within the business rescue regime without the control of the company being with the supervisor. It therefore provides the opportunity for something of a gap to be created of up to five business days during which the supervisor is not in place. It is unclear as to the impact of the decisions of the board of directors during this time. Under proposed section 143 it is the supervisor who is responsible to supervise and advise the management whilst the business rescue is in place but the ability to retrospectively do this (where the appointment is made five days later) is unclear. It may be desirable to resolve this by requiring the appointment of the supervisor to coincide with the commencement of the procedure.

\section{$5 \quad$ Supervision during the rescue process}

As with all rescue procedures there needs to be a period of investigation of the corporations business prior to making any decision as to the future. This period may be longer as in the North American models of rescue or shorter as in the Anglo-Australian models. There are various arguments for and against the shorter time frames adopted in Australia. ${ }^{53}$ The Harmer Report was clearly of the view that a short time frame was necessary in order to prevent abuse by the

52 See the proposed s 135.

53 Eg a longer period is likely to increase the chances of putting together a rescue package. One criticism that may be made of the Australian provisions is that in such a short time frame it is unlikely that the parties will be able to negotiate satisfactory outcomes. On the other hand a shorter time frame ensures that there is less chance for the management to use the length of time of the moratorium as a negotiating tool.

$117 / 211$ 
incumbent management of the company so as to protect the rights of creditors including secured creditors. ${ }^{54}$ This has resulted in the Australian provisions providing for a standard period of 28 days before the meeting of creditors to decide the future of the company. ${ }^{55}$ Recent amendments (not yet operable) have increased this period to 25 business days or effectively five weeks. ${ }^{56}$ This slight increase does not alter much in practical terms with the period still being a short one. It is possible to have the period extended by application to the court $^{57}$ and this is a relatively common application. The period of the moratorium may also be effectively increased by adjourning the meeting of creditors which may be done for a period of up to 60 days. ${ }^{58}$ It is clear that the time frames contemplated in the South African business rescue procedure are of a similar duration though slightly longer. The procedure requires the publication of a business plan within 25 business days after the date on which the supervisor was appointed unless extended by the court or a majority of the voting interests. ${ }^{59}$ The meeting to decide the fate of the plan is to be held within 10 business days after that publication. ${ }^{60}$ Thus the South African approach does fit closer to the Australian model than the North American approach and this is consistent with the other aspects of the scheme as well.

\section{$5.1 \quad$ Initial meetings}

There are other similarities between the systems as well in that there is an initial meeting of creditors in both jurisdictions. The meeting in the Australian

54 ALRC Harmer Report http://www.alrc.gov.au/ 11 Feb at par 98.

55 See s 439A. Extensions are made for administrations commenced in December and 28 days before Good Friday but this extension is for one further week.

56 Corporations Amendment (Insolvency) Act 2007 (Cth) sch 4. It may be noted that this legislation is at the time of writing yet to be proclaimed and hence is not yet in force. Again the extensions in December and before Good Friday are also extended to 30 business days or six weeks.

57 Under s 439A(6).

58 By adjourning the meeting under s $439 \mathrm{~B}(2)$ no decision is made and hence the voluntary administration will continue in accordance with s 435C.

59 Proposed s 153(6).

60 Proposed s 154(1). 
system is held within five business days of appointment ${ }^{61}$ but again recent amendments have moved this to eight business days. The first meeting under the Australian system has two functions; one is to appoint a committee of creditors if the creditors decide to do so and to replace the administrator if the creditors vote to do so. There is no other function for that meeting and it cannot end the administration. The function of the first meeting of creditors under the South African ${ }^{62}$ proposal appears to be limited to the supervisor informing the creditors of the belief that a rescue is a 'reasonable prospect' and to appoint a committee of creditors. ${ }^{63}$ There appears to be no possibility of removal of the supervisor at this meeting as under the Australian scheme. The South African scheme also contemplates a meeting of employee representatives which serves a similar function to the first meeting of creditors. ${ }^{64}$

This raises one significant difference between the Australian provisions and the South African approach. The Australian provisions generally create no special provisions for dealing with employees. In the recent amendments there has been specific consideration of the employees' position for the first time albeit in a limited manner. This was done by requiring the default position in any rescue plan to include the statutory winding up priorities ${ }^{65}$ unless specific approval was given by a vote of the employees or the court. ${ }^{66} \mathrm{It}$ is clear that there has been concern as to the employees' position in the South African proposal. This is understandable as it has been the Australian experience that at times the employees' position in the decision-making process has been one of disadvantage. ${ }^{67}$ The South African approach is to elevate the employees in

61 S 436E and Corporations Amendment (Insolvency) Act 2007 (Cth) see sch 4.

62 Note that it is proposed that the meeting must be held within 10 business days after appointment: see s 151.

63 See proposed s 150.

64 See proposed s 151.

65 Provided in s 556 which provide for priority for employees wages superannuation contributions along with leave entitlements and redundancy payments.

66 Corporations Amendment (Insolvency) Act 2007 (Cth) sch 1.

67 This has been because employees whose rights were not protected at least as well in a deed of company arrangement as in liquidation are required to incur the expense of $119 / 211$ 
terms of rights being given under proposed section 147 as regards being consulted on the development of the rescue plan and to propose an alternative plan. Further protection is granted to employees through the proposed section $139 .^{68}$ The additional concern as regards employees reflects the different social structures and conditions that exist in each jurisdiction rather than any fundamental difference in the underlying approach.

\subsection{Investigations}

A critical function in both schemes is investigations of the company. In Australia the administrator is obliged under Division 4 in Part 5.3A to investigate the company's affairs. ${ }^{69}$ The administrator is assisted in this task by various provisions that require the directors to assist. ${ }^{70}$ The South African proposal deals with this issue by requiring investigation under the proposed section 144 and the directors' assistance under proposed section 145. One difference that emerges from consideration of this issue is the fact that the Australian provisions are aimed at considering the interests of the creditors in the company being wound up. The emphasis in the South African proposal appears to be confined more to a consideration of the rescue plan. The proposal in section 144 is that the supervisor must if he or she concludes that there is no reasonable prospect for the company to be rescued must inform the court, affected persons and the company and apply for an order to discontinue the proceedings. It is clearly not within the purview of the procedure to allow the company to move seamlessly into liquidation. ${ }^{71}$ The Australian provisions are designed to make that transition as costless as possible ${ }^{72}$ and hence it is

applying to court to have the deed set aside even though such an order would be likely granted.

68 Discussed below.

69 See particularly s 438A.

70 A number of provisions require the directors to assist such as s 438B, 438C and 442A.

71 le further steps are necessary before winding up can commence.

72 At the second meeting of creditors the creditors can resolve that the company be wound up (s 439C) and if that happens the company is deemed to have commenced to be wound 
required that the administrator comments upon that option. This flexibility between the procedures for dealing with an insolvent company was a key feature of the Harmer Report which wanted to develop within the alternatives an easy way to move the company from the investigation stage to the procedure which best suited the particular circumstances. This feature was fundamental to the arrangement of Part 5.3A even though it is often overlooked. If a company cannot be rescued than if it remains insolvent the alternative is only liquidation hence there is logic in allowing that procedure to commence immediately. The South African proposals do allow for a supervisor to apply to the court for the winding up when there is no reasonable prospect of rescue however it appears that this may not happen after the plan has been rejected as the business rescue proceedings are by the proposed section 135(2)(b), deemed to end. ${ }^{73}$ There appears no other basis in the proposed chapter 6 or in proposed sections dealing with voluntary ${ }^{74}$ or court ordered windings up ${ }^{75}$ that will allow for a supervisor to apply for the winding up. This will presumably result in the normal procedures being required to commence the winding up. In this regard the Australian procedures do have some advantages given that in rejecting a rescue plan the creditors are suggesting that there is little prospect of saving the company and if it is insolvent the winding up course seems appropriate. Even if it is determined that the Australian approach is unsuitable, it would seem desirable that the legislation deal explicitly with what should happen if the plan is rejected. In this respect another factor that could be considered is whether a liquidator should be able to initiate the business rescue proceedings in an appropriate case. ${ }^{76}$

up under a creditors' voluntary liquidation with the administrator as the liquidator: see $\mathrm{S}$ $446 \mathrm{~A}$.

73 The ending of the proceedings would also presumably terminate the right under proposed s 144(2) to apply to the court for winding up as this is operative "during business proceedings".

74 Proposed s 29.

75 Proposed s 30.

76 By way of example see s 436B of the Corporations Act 2001 (Cth).

$121 / 211$ 


\subsection{Moratoriums}

In any corporate rescue system there needs to be a circuit breaker that provides a breathing space whilst a consideration is given to the prospect of saving the company.

In Australia as part of the moratorium provisions there is during the period of the administration a general prohibition on the rights of owners or lessors of property that is in the possession of the company. ${ }^{77}$ Because a major aim of the administration period is to provide the company with the opportunity to consider a rescue, the appointment of an administrator has a significant impact on the rights of unsecured creditors and this is manifested in a number of ways. Thus during the administration:

- court proceedings against the company are automatically stayed without the written consent of the administrator or the court; ${ }^{78}$

- the execution process if started cannot continue ${ }^{79}$ and

- any other attempt to enforce a judgement is barred. ${ }^{80}$

The Harmer Report ${ }^{81}$ recommended the moratorium apparently on the basis of promoting an orderly dealing with a company's affairs. ${ }^{82}$ The principle which justified such a limited interference was considered to be based upon the -

77 S 440C. See also Robinson 1996 Australian Business Law Review at 434-436.

78 S 440D. There is an exception for criminal proceedings or any others that are prescribed under $\mathrm{s} 440 \mathrm{D}(2)$. The section will only operate where what is being considered is really a claim against the company for if it is some other type of claim then $S 440 \mathrm{D}$ will not be applicable: J \& B Records v Brashs (1994) 13 ACSR 680.

79 S 440G.

80 S 440F.

81 ALRC Harmer Report http://www.alrc.gov.au/ 11 Feb at par 56.

$82 \mathrm{Ibid}$ at par 97. 
promotion of an orderly dealing with a company's affairs so as to enable a more beneficial realisation of assets on winding up or possibly the rehabilitation of the business of the company.

As with other creditors, those who are secured by way of a charge may face restrictions on their rights once an administrator is appointed. The Harmer Report $^{83}$ argued that there were three principles that justified the interference. These were:

- promotion of an orderly dealing with the company's affairs;

- recognition of the debtor's interests in the assets that are subject to the security; and

- recognition that the particular asset that is subject of the security may be necessary for any reorganisation to be successful.

The basic prohibition ${ }^{84}$ is against a person enforcing a charge on the property of the company during the period of the administration. This is subject to a number of exceptions in Division $7 .^{85}$ One of the difficulties that has arisen is the fact that the legislation in this Division uses the term 'charge' rather then the more generic secured creditor. This distinction has been significant in placing limits on the rights of the administrator. In Osborne Computer Corporation Pty Ltd $v$ Airroad Distribution Pty $L t d^{86}$ it was held that the term charge did not include a lien or pledge. These were regarded as possessory security only and hence being different in nature to a charge which implied a right even without possession.

One secured creditor who can assert rights despite the appointment of an administrator is one having a charge over the whole or substantially the whole

83 Ibid at par 96.

84 S 440B.

85 See specifically s $441 \mathrm{~A}$ to $441 \mathrm{E}$.

86 Osborne Computer Corporation v Airroad Distribution (1995) 17 ACSR 614.

$123 / 211$ 
of the assets of the company. ${ }^{87}$ Potentially the exception ${ }^{88}$ may thwart the administration process as these secured creditors could generally act to appoint their own receiver. This has not proven to be the case.

Under the South African proposal there is a general moratorium provided for in the proposed section 136. This provides that no legal proceeding against the company or in relation to its property may be commenced or proceeded with without the consent of the supervisor or the leave of the court. ${ }^{89}$ The South African proposal also provides that the company may only dispose of property in the ordinary course of business or in a bona fide transaction as approved by the supervisor. ${ }^{90}$ The subsection does also allow for the disposal as part of the implementation of the business rescue plan once it has been approved under section 155. Whilst this has similarities to the Australian provisions it does highlight one very significant difference between the two systems. The South African proposal provides for the duration of 'business rescue proceedings' to cease, inter alia, when a supervisor has filed a Notice of Substantial Compliance with any business rescue plan $^{91}$ that has been adopted under the proceedings. The Australian procedure has two distinct phases. The first is the voluntary administration procedure which has significant moratorium attached to it for all creditors and owners of property. This is the moratorium as described above. However once a rescue plan has been adopted by the second meeting of creditors, those provisions imposing the general moratorium come to an end. ${ }^{92}$ The operation of the rescue plan or deed of company

87 Under s 441A.

88 Where a holder of a charge has a charge over the whole or substantially the whole of the assets of the company.

89 There are exceptions for set-off, criminal proceedings or those involving the company as trustee of property.

90 See s 137(1).

91 This is required under proposed $s$ 155(7). It is not clear from that provision when that notice does need to be filed as it is when the plan has been 'implemented'. This may mean once it is in place or it may imply that the plan has been satisfactorily completed. The author could find no illumination on this point.

92 Under the Australian procedure the voluntary administration under s 435C. 
arrangement as it is termed in the legislation, results generally in only unsecured creditors being bound. The secured creditors and owners of property in the possession of the company are at that time free to enforce their security or recover their property in accordance with their pre-appointment rights unless they have voted in favour of the deed or there is an order of the court. ${ }^{93}$ The proposed South African procedure appears to bind the rights of all persons in relation to the rights in respect of the company's property without the approval of the supervisor, as part of the rescue plan or an order of the court. ${ }^{94}$ There is provision for rights to be exercised in accordance with an "agreement made in the ordinary course of the company's business" 195 but it is unclear what that may be intended to cover as it seems to suggest an agreement made after the appointment of the supervisor for if not it would seem to allow the enforcement against the property of the company at any time. Where the company does dispose of property that is either secured or owned by another, the company is required to pay the amount received to the owner or secured creditor or provide security.

As well as the moratorium that exists in the South African proposals any supplier to the company of products considered essential to the conduct of the business must continue the supply unless there is an agreement in relation to other terms or there is a court order. ${ }^{96}$ There is no such provision in the Australian procedure so that it appears this will make the procedure more debtor friendly than the equivalent Australian procedure. Further as part of the protection of employees theme that runs through the South African procedure, the employees continue to be employed on the same terms and conditions ${ }^{97}$ except to the extent that:

93 See s 444D and s 444F.

94 See proposed s 137(1)(b).

95 Under proposed s 137(1)(b)(ii)(aa).

96 See proposed s 140.

97 See proposed s 139(1)(b). 
- changes occur in the ordinary course of attrition;

- an approved business rescue plan provides otherwise; or

- the employees and the company agree to different terms and conditions that benefit the company.

Again this provides much more protection than appears under the Australian provisions. In the Patrick's case in Australia, ${ }^{98}$ the High Court made it clear that a fundamental aspect of the administrator's task was to operate the company as he or she saw fit and that accordingly even where there may was possible breaches of industrial legislation, it was not prepared to order that employees must be retained by the company during a voluntary administration.

\subsection{Role of supervisors}

In Australia the administrator in the voluntary administration procedure is given effectively total control over the company. The administrator has broad powers in terms of management as the power of other officers is suspended. ${ }^{99}$ In addition the administrator has the power to appoint and remove directors, as well as execute documents on behalf of the company and do "whatever else is necessary" for the purposes of Part 5.3A. ${ }^{100}$ It may be noted that these powers exist only up to the point when the creditors decide the fate of the company though and any powers during a deed of company arrangement will depend

98 Patrick Stevedores Operations (No 2) v Maritime Union of Australia 195 CLR 1; 27 ACSR 53; 572 ALJR 873; 79 IR 339; 153 ALR 643; [1998] HCA 30 where Brennon cj, McHugh, Gummow, Kirby and Hayne jj stated (195 CLR at 38): "It is for the administrator, in the exercise of the discretionary powers conferred by section 437A, to decide whether or not to carry on the company's business and the form in which it should be carried on during the administration."

99 Under s 437A the administrator has control of the company's business, property and affairs as well as the ability to carry on or terminate as well as sell the business. He or she may also perform any of the functions or powers of officers when the company is not in administration: see Brash Holdings v Shafir (1994) 12 ACLC 619.

100 See s 442A. 
upon the wording of the deed itself. ${ }^{101}$ There are in addition specific duties of the administrator in terms of reporting to the creditors as to the desirability of taking a particular course of action at the meeting as well as duties to report to regulatory authorities about the company activities where breaches of the Corporations Act become apparent.

Beyond the specific powers and duties of the administrator there is the broader role that the administrator must play in the Australian system. The administrator must not only run the company's business but also act fairly between the creditors and if possible devise a plan for the company's future. All this must be done in a relatively short period of time. The supervision of the administrator is undertaken by the regulatory authority Australian Securities and Investments Commission (ASIC) as well as specifically by the court through the ability of aggrieved parties to apply to the court to have matters decided by the administrator reviewed. ${ }^{102}$ At the time of the introduction of Part 5.3A Australia had a regulated insolvency profession but the focus was upon liquidation not corporate rescue. There is no doubt that the development of the administration procedure placed new demands upon insolvency practitioners and hence there has been a review by ASIC in terms of its registration procedure. ${ }^{103}$ The role of the administrator is critical to the success or failure of the rescue regime in Australia. The administrator must have the confidence of both the creditors and the debtor company. The debtor will not use the procedure if the administrator does not have their confidence and a major point of the procedure encouraging early dealing with the insolvency - will be lost. On the other hand the creditors must have confidence in the administrator in terms of any proposal to rescue the company, otherwise they will reject any plan proposed. Having an administrator with very wide powers of control overcomes some of the criticism

101 Howard v Mechtler (1999) 30 ACSR 434.

102 See s 447E.

103 See now ASIC Regulatory Guide 186 http://www.asic.gov.au/ 30 Oct. 
of the American model of rescue where the debtor remains in possession as a general rule. ${ }^{104}$

The South African proposal also places much responsibility on the supervisor. It is set out in proposed section 143 that the supervisor has the power "to supervise and advise the management of the company". It is also proposed that the supervisor has the power to veto or approve significant management decisions and authorise borrowings. Like the Australian administrator there is the power to remove managers and appoint others. It does appear though that the existing management will remain in place so that a cooperative model of management between the supervisor and the board is suggested by the proposal than is the case in Australia. This may be desirable given the need for cooperation in any successful rescue. It may result in greater numbers of entities continuing in existence although it also runs the risk of creditors being more suspicious of the procedure. As the supervisor is to be registered then this may reduce those concerns. One other aspect of the South African model is that the supervisor is to be an officer of the court whereas in Australia that is not the case. Again this is likely to increase the position of the supervisor in terms of his or her independence and perceived independence.

\section{Decision-making in the rescue process}

A final stage in any corporate rescue regime is the decision-making phase where the fate of the company is decided. As with the commencement procedures, there are alternative means of doing this in different jurisdictions and it is argued that the Australian model is somewhat simplistic in its

104 Bradley and Rosenzweig 1992 Yale Law Journal at 1052 state: "The social costs of Chapter 11 proceedings are well known. Bankruptcy law encourages corporate managers to reorganise their firms under court supervision, which effectively invites them to create a net equity position for stockholders by overstating expected cash flows and understating risk." 
approach. The Australian decision-making model relies exclusively on the creditors voting to either wind up the company, to place it under a deed of company arrangement or to simply return the company to its previous condition at a second meeting of creditors. ${ }^{105}$ The third option is not adopted in most cases so the creditors will be deciding the matter as either liquidation or a deed. The system therefore relies upon the creditors being able to make the correct decision as regards the future of the company and in this respect the information provided by the administrator is critical. ${ }^{106}$

It is interesting that a very pragmatic approach to the voting is adopted in Australia despite the decision being critical to the procedure. There is a division of the votes into class and number but there is no division based upon priority. Hence there is no division into classes as such. ${ }^{107}$ This results in a relatively quick decision. The method of voting is not specified clearly in the legislation in relation to voluntary administration and it is only in the Corporations Regulations made pursuant to the Corporations Act that the method is spelt out. ${ }^{108}$ The regulations provide for a vote to be put to the meeting with a simple majority in number and in value required to pass a resolution. If there is a split by way of different voting between the two groups, the chair of the meeting (who must be the administrator) has a casting vote. Where the casting vote is used, there are rights of appeal to affected parties. ${ }^{109}$ The aim as with many of the provisions in this Part appears to be to have a quick decision with minimum formalities and that if stakeholders feel aggrieved they should apply to the court for an adjudication and remedy.

105 S 439A and 439C.

106 ALRC Harmer Report http://www.alrc.gov.au/ 11 Feb at par 110-111.

107 Recent changes to the legislation have enabled employees to vote specifically where any deed proposes to alter the statutory priorities on winding up in its distribution: see Corporations Amendment (Insolvency) Act 2007 (Cth) sch 1.

108 Specifically the convening and conduct of, and voting at, a meeting convened under Part $5.3 \mathrm{~A}$ is governed by reg 5.6.12 to 5.6.36A of the Corporations Regulations: see reg 5.6.11 (2). See Young $v$ Sherman [2001] NSWSC 1020 at par 84; (2001) 40 ACSR 12.

109 S 600A-C. 
The South African proposal is for a meeting of the creditors "and any other holder of a voting interest" ${ }^{110}$ to consider the rescue plan. A voting interest is effectively defined under proposed sections 148(4) to (7) and extends to employees where they may be retrenched under the proposed plan or who may have their conditions adversely affected under the plan. It also includes secured creditors only to the extent of their shortfall in security. These definitions are somewhat different to the Australian provisions where employees are not treated as a separate group and hence may only vote if considered to be a creditor. Again this shows the employee protection theme in the South African proposals. There is no definition of creditor in the Australian Corporations Act and hence it takes on its ordinary meaning. In addition in Australia, secured creditors may vote in the creditors' meeting under section 439A without surrendering their security. ${ }^{111}$ The South African proposals seem more in line with general insolvency principles in this regard.

The decision on a rescue plan in respect of the South African proposal appears to be decided in a negative manner. Under proposed section 155 the plan is defeated if it is opposed by the holders of more than $50 \%$ of the voting interests. It is not clearly stated whether this is number or value but the reference to interests may suggest value. The plan is also defeated if opposed by more than $25 \%$ of the 'independent creditors'. This group is defined ${ }^{112}$ as any creditor including employees provided they are not related to the company, a director or the supervisor. This shows, much like the Australian decisionmaking process, a desire to have the adoption of any rescue plan to be decided quickly as there is no division into classes and no need for further court approval. However unlike the Australian provisions which, as noted above, ignore shareholder interests, proposed section 155 will require a vote of shareholders or a class of shareholders where the plan "affect[s] the interests

110 As defined under proposed s 130.

111 See generally reg 5.6.24 of the Corporations Regulations and in particular 5.6.24(4).

112 See proposed s 130. 
of any class of shareholders". Approval here will require a simple majority. There may be some clarification needed as to what is meant by affecting a class of shareholders but it does provide for a broader range of plans to be adopted than is possible under the Australian provisions. ${ }^{113}$

Another feature of the South African proposal which is not allowed for under the Australian provisions is the option of the supervisor to seek a vote to prepare a revised plan. ${ }^{114}$ Further, this may be done through a vote by the holders of any voting interests at the meeting. ${ }^{115}$ There is no specification as to how this vote is to be taken and hence it does not appear to require the approval of $75 \%$ of "independent creditors' voting interests" in the manner that the plan approval does.

In Australia there is an emphasis on having the company wound up when the deed is rejected by the creditors. ${ }^{116}$ Although it is possible for the meeting to be adjourned $^{117}$ there are only three alternatives provided for at the meeting of creditors and none of those specifically involve an extension of time to consider a revised rescue plan. As a result it may be expected that the South African approach may result in more plans being adopted than is the case in Australia. It may result in more strategic behaviour though, by supervisors in conjunction with company management to delay liquidation. Such a problem could be overcome if there is a strong court reaction to such situations and the regulation of the supervisors by the registration authority is effective.

113 Where a proposal involves arrangements with shareholders in Australia it can only be achieved through the Scheme of arrangement provisions in Part 5.1 of the Corporations Act.

114 See proposed s 156(1).

115 See proposed s 156(1)(b).

116 Under s 439C there are only choices to wind the company up or simply return it to its previous position if the deed of company arrangement is rejected.

117 Under s 439B(2). 


\section{$7 \quad$ Conclusions}

This article has made some comparisons between the Australian corporate rescue provisions and those proposed to be adopted in South Africa in the Companies Bill 2007. Whatever the particular content of the legislation it seems that the aims of the legislation and that proposed in South Africa are almost identical. This of itself is significant given that there is debate over the appropriateness of specific corporate rescue legislation at all. The comparison above results in two themes emerging as differences between the approaches in each jurisdiction. First, there is a clear concern in the South African provisions with the position of employees which is not apparent in Australia. That is not to suggest that the Australian provisions ignore employees completely but in South Africa it is proposed that their involvement will be more direct and are recognised throughout as being in a special position vis a vis other creditors. On the other hand there appears to be less concern in South Africa with the position of secured creditors than is evident in the Australian provisions. Concern about the support for the procedure by institutional lenders is possibly at the core of the stronger position of secured creditors in the Australian legislation.

Second, the proposed South African provisions do not facilitate transition to winding up in the same manner as the Australian provisions. There is within the South African proposal a genuine attempt to give the company every chance at developing a rescue plan by allowing for alternative proposals to be developed. There is no direct transition after the rejection of a plan to winding up as there is in Australia. The Australian provisions are structured more to provide for liquidation as a direct alternative for creditors rather than proposals for an alternative plan. This is also reflected in the style of reports provided to the creditors. The South African proposals do not divide the procedure clearly into a decision-making stage and the period whilst the company is operating under the rescue plan. The Australian provisions provide clearly for a break between 
a period where the creditors have yet to make a choice about the company's future and the period once a plan (or deed of company arrangement) has been adopted. The legislation clearly divides these periods in terms of major issues such as the moratorium the power of the administrator and so on.

In many respects the South African model of rescue as proposed does cover many similar areas as identified in the Australian legislation and these include aspects of the supervisors position, the periods for holding meetings and so on. There are sufficient similarities to suggest that much will be common in the experience if they are adopted into the legislation. However differences will remain and it will be interesting to review the procedure in the coming years to see if the scheme is as popular as it is in Australia.

\section{Bibliography}

Anderson 1999 Australian Journal of Corporate Law 107

Anderson C "Finding the Background of Part 5.3A of the Corporations Law" 1999 (10) Australian Journal of Corporate Law 107

Anderson 2001 Insolvency Law Journal 4

Anderson C "Commencement of the Part 5.3A Procedure: Some

Considerations from an Economics and Law Perspective" 2001 (9) Insolvency Law Journal 4

Bainbridge 2003 Northwestern University Law Review 547

Bainbridge S "Director Primacy: The Means and Ends of Corporate Governance" 2003 (97) Northwestern University Law Review 547

Baird 1986 Journal of Legal Studies 127

Baird DG "The Uneasy Case for Corporate Reorganizations" 1986 (15)

Journal of Legal Studies 127 
Baird and Rasmussen 55 Stanford Law Review 751

Baird DG and Rasmussen RK "The End of Bankruptcy" 55 Stanford Law Review 751

Barondes 1998 George Mason Law Review 45

Barondes R de R "Fiduciary duties of Officers and Directors of Distressed Corporations" 1998 (7) George Mason Law Review 45

Bradley and Rosenzweig 1992 Yale Law Journal 1052

Bradley M and Rosenzweig M "The Untenable Case for Chapter 11" 1992 (101) Yale Law Journal 1043

Burdette D Comments on the Companies Bill

Burdette D Comments on the Companies Bill - Chapter 6 Business Rescue 16 March 2007

CASAC Corporate Voluntary Administration Final Report June 1998 Companies and Securities Advisory Committee Corporate Voluntary Administration Final Report June 1998

DTI Explanatory Memorandum Companies Bill 200714

Department of Trade and Industry South Africa Explanatory Memorandum Companies Bill 2007

Fletcher and Crabb Insolvency Act Fletcher IF and Crabb L Insolvency Act 1986 with Annotations (Sweet \& Maxwell London 1986) 
Jackson Logic and Limits of Bankruptcy Law

Jackson T The Logic and Limits of Bankruptcy Law (Beard Books Washington DC 2001)

Pilcher, Uther and Baldock Australian Companies Act Pilcher NG, Uther AH and Baldock WJ The Australian Companies Act (Butterworths Sydney 1937)

Robinson 1996 Australian Business Law Review at 434-436 Robinson WC "Statutory Moratorium on Proceedings against a Company" 1996 (24) Australian Business Law Review 429

\section{Register of legislation}

\section{South African}

Companies Bill 2007

Companies Act 61 of 1973

\section{Australian}

Corporations Act 2001 (Cth)

Corporate Law Reform Act 1992 (Cth)

Corporations Amendment (Insolvency) Act 2007 (Cth)

\section{United Kingdom}

Joint Stock Companies Arrangement Act 1870

\section{Register of court cases}

Aloridge Pty Ltd v Christianos (1994) 12 ACLC 237

Australasian Memory Pty Ltd v Brien (2000) 200 CLR 270

Brash Holdings Ltd v Shafir (1994) 12 ACLC 619

Dallinger v Halcha Holdings Pty Ltd (1996) 14 ACLC 263

Howard v Mechtler (1999) 30 ACSR 434 
J \& B Records Ltd v Brashs Pty Ltd (1994) 13 ACSR 680

Kalon Pty Ltd v Sydney Land Corp Pty Ltd [No 2] (1998) 26 ACSR 593

Kazar v Duus (1998) 29 ACSR 321

Osborne Computer Corporation Pty Ltd v Airroad Distribution Pty Ltd (1995) 17

ACSR 614

Patrick Stevedores Operations (No 2) Pty Ltd v Maritime Union of Australia 195 CLR 1; 27 ACSR 53; 572 ALJR 873; 79 IR 339; 153 ALR 643; [1998] HCA 30

Young v Sherman [2001] NSWSC 1020; (2001) 40 ACSR 12

\section{Register of Internet resources}

ALRC Harmer Report http://www.alrc.gov.au/ 11 Feb

Australian Law Reform Commission Report No 45 General Insolvency

Inquiry 'Harmer Report' (AGPS Canberra 1988) [Found on internet]

http://www.alrc.gov.au/inquiries/title/alrc6\&36\&45/index.htm [Date of use 11 February 2008]

ASIC Regulatory Guide 186 http://www.asic.gov.au/ 30 Oct Australian Securities and Investments Commission Regulatory Guide 186: External Administration Liquidator Registration 30 September 2005 [Found on internet]

http://www.asic.gov.au/asic/pdflib.nsf/LookupByFileName/ps186.pdf/\$file/ps 186.pdf [Date of use 30 October 2007]

CAMAC Discussion paper http://www.camac.gov.au 14 Feb

Corporations and Markets Advisory Committee Rehabilitating large and complex enterprises in financial difficulties Discussion paper September 2003 [Found on internet] http://www.camac.gov.au [Date of use 14 February 2008] 
CAMAC Report http://www.camac.gov.au 14 Feb

Corporations and Markets Advisory Committee Rehabilitating large and complex enterprises in financial difficulties Report October 2004 [Found on internet] http://www.camac.gov.au [Date of use 14 February 2008]

Parliamentary Joint Committee Issue Paper http://www.aph.gov.au/ 14 Feb Parliamentary Joint Committee on Corporations and Financial Services Improving Australia's Corporate Insolvency Laws: Issue Paper May 2003 [Found on internet] http://www.aph.gov.au/senate/committee/corporations ctte/ail/issuespaper.doc [Date of use 14 February 2008]

\begin{tabular}{ll}
\multicolumn{2}{l}{ List of abbreviations } \\
AGPS & Australian Government Publishing Service \\
ALRC & Australian Law Reform Commission \\
ASIC & Australian Securities and Investments Commission \\
CAMAC & Corporations and Markets Advisory Committee \\
CASAC & Companies and Securities Advisory Committee \\
ch & chapter(s) \\
DTI & Department of Trade and Industry \\
par & paragraph(s) \\
reg & regulation(s) \\
s & section(s) \\
sch & schedule(s)
\end{tabular}

